\title{
REVISIONISMOS INESPERADOS \\ LA CONTRAMARCHA VANGUARDISTA DE GAMALIEL CHURATA Y ARTURO BORDA
}

\author{
POR \\ Elizabeth Monasterios PÉrez \\ University of Pittsburgh
}

En lo que va del siglo XXI, la historia cultural peruana y boliviana ha registrado acontecimientos que hace apenas un par de décadas parecían imposibles: repensar el canon literario y reparar el error histórico de haber ignorado, durante todo el siglo $\mathrm{XX}$, a dos obras y a dos escritores que llevaron la experiencia vanguardista a campos inexplorados por las teorías estéticas de la vanguardia histórica. Me refiero al peruano Gamaliel Churata (1897-1969) y al boliviano Arturo Borda (1883-1953), los bárbaros que llevaron a terreno estético subjetividades indígenas y urbano-populares que además de resultar ajenas al espíritu del arte occidental, desestabilizaban su universalidad.

Gamaliel Churata fue el pseudónimo con el que a partir de 1924 se dio a conocer Arturo Peralta Miranda, una de las personalidades más interesantes del proceso cultural andino de la primera mitad del siglo XX. En lengua aymara "Churata" significa el elegido y "Gamaliel" es una alusión a Gamaliel el Viejo, uno de los doctores de la ley que conminó a los israelitas a "no perseguir" a los apóstoles ni "impedir su prédica" ("Hechos de la Apóstoles" 5:38-39). Semejante combinación de epistemología aymara y contexto bíblico no es arbitraria ni acusa incoherencias. Tampoco, como mostraré en el desarrollo de este trabajo, se presta a lecturas mesiánicas. Obedece más bien a la excepcionalidad que rodeó la formación intelectual de este escritor, iniciada en Puno bajo la tutela de un padre (Don Demetrio Peralta), que además de haber fundado a principios de siglo XX la Sociedad Fraternal de Artesanos de Puno, donde se reunía el anarquismo indígena de la provincia, había desafiado al catolicismo gamonalista convirtiéndose en predicador anarco-evangelista. Sus hijos, por tanto, crecieron en un ambiente radicalmente politizado a favor de demandas indígenas y bajo la influencia de la retórica liberadora del Nuevo Testamento. En Bolivia, donde vivió durante más de treinta años (primero en 1918, cuando sólo tenía 18 años y después, a raíz de un exilio, desde 1932 a 1964), ${ }^{1}$ asumió el calificativo de "bárbaro" por haber fundado,

\footnotetext{
1 El exilio de Churata se produjo a raíz de las turbulencias políticas que rodearon la caída de Leguía y el
} 
junto a Carlos Medinaceli, el grupo literario Gesta Bárbara (Potosí, 1918), que en palabras del mismo Churata fue "una contramarcha [...] allí maduró el genio bárbaro [...] allí conocimos a España y descubrimos a América" (Trigo 105 y 113). En el Perú, Churata fue contemporáneo a los escritores de la llamada "Generación Centenario" (José Carlos Mariátegui, Luis Alberto Sánchez, José Sabogal, Luis Valcárcel, César Vallejo, entre otros), aun cuando nunca realmente se integró a ella. Al contrario, lideró desde Puno una contramarcha cultural que él mismo reconoció como "vanguardismo del Titikaka" y Luis Alberto Sánchez caracterizó como "el hecho más curioso e insólito de la literatura del Perú". La opción de escribir "Titikaka" y no "Titicaca" responde a un proyecto de dislocar la ortografía hispana para acercarse a la "bárbara" y "plebeya" de Guamán Poma y, simultáneamente, conservar en el castellano la sonoridad del aymara.

El otro escritor que obligó a repensar el canon literario, ahora desde Bolivia, fue el carismático e irreverente Arturo Borda, conocido entre sus contemporáneos con el sobrenombre de "el loco", en alusión a su proyecto de incorporar lo marginal-popularurbano en el horizonte de la nacionalidad y, con esa fuerza, demoler la historia moderna de Bolivia, la hegemonía hispánica y el carácter elitista que la literatura y el arte tuvieron durante gran parte del siglo XX. Además de escritor, Borda fue un tenaz artista plástico (se estima que pintó alrededor de tres mil cuadros), periodista, anarquista y activista social que rechazó para sí el rol de "intelectual" o "bohemio" por considerar que se trataba de expresiones higienizadas tendientes a domesticar la rebeldía expresada a través del arte y la literatura. En clara actitud de desafío a lenguajes domesticados, Borda se declaró lari, expresión aymara alusiva a una existencia anónima y marginal, a un sujeto que habita los bordes entre lo social y lo salvaje. De aquí que en muchas ocasiones se haya autoidentificado como "Calibán".

Esta breve introducción sirve para entender que entramos a dialogar con escritores prolíficos y difícilmente clasificables desde parámetros estéticos convencionales. No son "novelistas", ni "cronistas", ni "poetas", ni "cuentistas", ni "dramaturgos", ni "ensayistas", pero cometen esas y otras modalidades escriturales, distorsionando siempre la convencionalidad de las formas clásicas. Churata, además de activista cultural,

ascenso de Sánchez Cerro al poder. Ganador de las elecciones de 1931, en las que salió derrotado Víctor Haya de la Torre, Sánchez Cerro desató una represión estatal que persiguió, apresó y exilió por igual a apristas y comunistas. Churata, que en principio había apoyado la "revolución militar" de Sánchez Cerro contra la oligarquía Leguiísta, vivió en carne propia las repercusiones que esa represión tuvo en Puno. Se vio obligado a renunciar a su cargo de Director de la Biblioteca Municipal de Puno; su casa y su biblioteca fueron allanadas, perdiéndose para siempre una "novela de tesis socialista" y otra de "intención vernácula" que había escrito en los años veinte. A principios de 1932 fue encarcelado por más de un mes en la Prefectura de Puno, falsamente acusado de insubordinar a los estudiantes de San Carlos. A fines de abril de ese mismo año ya estaba en La Paz en calidad de exilado, sin dinero y con la intención de "rumbear" a Buenos Aires.

Revista Iberoamericana, Vol. LXXXI, Núm. 253, Octubre-Diciembre 2015, 989-1013 
periodista, promotor de El Boletín Titikaka, ${ }^{2}$ del ayllu Orkopata ${ }^{3}$ y de una contramarcha cultural que él mismo denominó "vanguardismo del Titikaka", ${ }^{4}$ es autor de un libro monumental (más de 500 páginas) escrito durante toda la primera mitad del siglo XX y recién publicado en La Paz en 1957: El pez de oro. Retablos del Laykhakuy. ${ }^{5}$ Borda, desde un activismo político anarquista y a caballo entre la literatura y las artes plásticas escribió, entre 1902 y 1927, otro libro monumental publicado póstumamente en 1966 en tres extensos volúmenes que hacen un total de 1659 páginas: El loco.

2 Revista vanguardista que funcionó como órgano de difusión del ayllu-Orkopata (agrupación que reunió a intelectuales mestizos e indígenas de la provincia de Puno). Entre 1926 y 1930 el Boletín Titikaka publicó 34 números dedicados a la exploración de una nueva estética, referida como "estética andina" y a la politización de las culturas andinas. Hasta el momento, los estudios más serios que se han hecho del Boletín Titikaka son los de Miguel Angel Rodríguez ("Guía del Boletín Titikaka"); David Wise ("Vanguardismo a 3800 metros: el caso del Boletín Titikaka"); Cynthia Vich (Indigenismo de vanguardia en el Perú: un estudio sobre el Boletín Titikaka) y Juan Zevallos Aguilar (Indigenismo y nación. Retos a la representación de la subalternidad aymara y quechua en el Boletín Titikaka (1926-1930). También importantes son los aportes de Vicky Unruh en Latin American Vanguards, Jorge Schwartz en Las vanguardias latinoamericanas, las "Presentaciones" de Dante Callo Cuno a la edición facsimilar del Boletín, y los trabajos de Yazmin López Lenci (El laboratorio de la vanguardia literaria en el Perú) y Dorian Espezúa Salmón ("Vanguardismo andino en el Boletín Titikaka").

3 Invariablemente, la crítica se refiere a este colectivo en términos de "Grupo Orkopata". Revisando los escritos de Churata, sin embargo, me he dado cuenta de que mucho más apropiado es identificarlo como "ayllu Orkopata", respetando así la percepción que el mismo Churata tuvo de los hechos. En una de sus últimas intervenciones públicas en Puno, se refirió a este colectivo como "escuela Orcopata" y la caracterizó como "el ayllu" de donde surgió esa contramarcha cultural que fue el vanguardismo del Titikaka ("Conferencia" 64).

4 En La vanguardia plebeya del Titikaka. Gamaliel Churata y otras beligerancias estéticas en los Andes, estudio en detalle la formación y funcionamiento de esta vanguardia, que en líneas generales fue una contramarcha cultural con capacidad de provocar un "debate vanguardista" y un "debate indigenista" que supera cualquier expectativa y reclama la atención crítica que hasta ahora no ha merecido. Un adelanto de esta investigación puede verse en mi artículo "La vanguardia plebeya del Titikaka", citado en la bibliografía.

5 Por palabras del mismo autor sabemos que la escritura de El pez de oro se inició en las aulas escolares de Puno a principios del XX ("Conferencia" 64), lo que ha llevado a muchos críticos a suponer que el libro fue escrito durante la primera juventud del escritor. En la primera edición del libro, sin embargo, Churata consigna la reescritura del Pez de oro a un periodo temporal mucho más largo, que va de 19271957, coincidiendo con los años de publicación del Boletín Titikaka en Puno y los del exilio boliviano (El Pez de oro 148). Estas precisiones ayudan a entender que estamos ante un libro escrito a lo largo de muchos años de activismo político y cultural en Puno fundamentalmente, pero también en La Paz. Se lo podría pensar como una escritura jayani (que tiene mucho tiempo de duración) en la que concurren la infancia de un llokalla puneño, la primera juventud de un bohemio andino y, de manera mucho más decisiva, el aprendizaje Orkopata y la candente experiencia boliviana.

Revista Iberoamericana, Vol. LXXXI, Núm. 253, Octubre-Diciembre 2015, 989-1013 


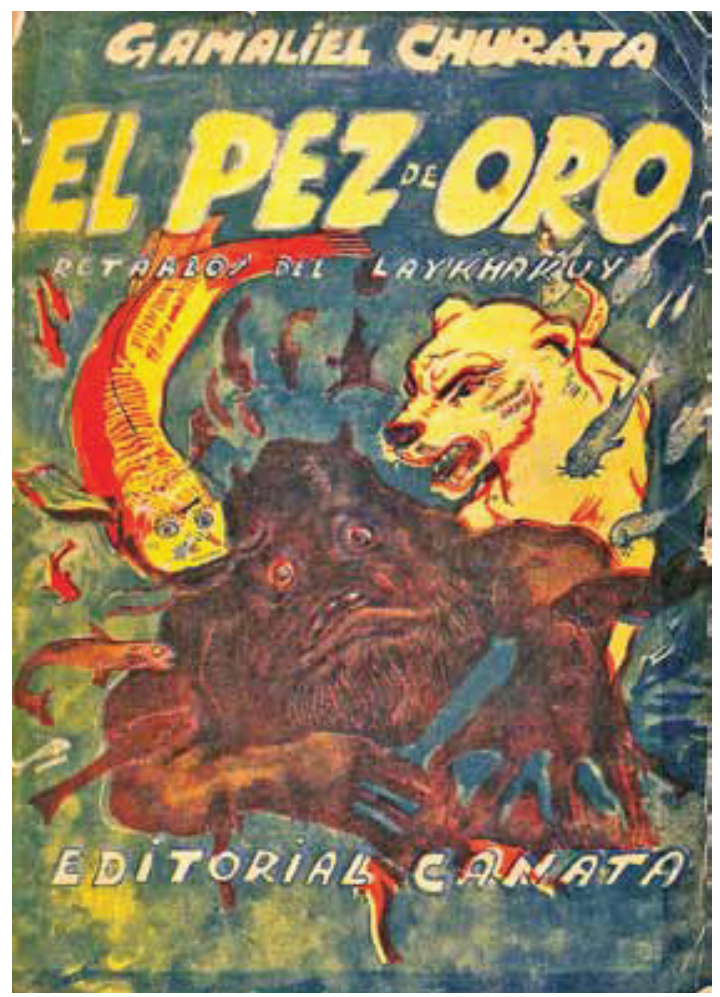

Portada de la primera edición de El pez de oro La Paz: Editorial Canata, 1957

Foto: Agatha Monasterios-Ramírez

Hasta la primera década del siglo XXI, ambos libros contaban únicamente con una primera edición agotada, situación que los convertía en criaturas extintas a las que el lector contemporáneo tenía poca o ninguna posibilidad de acceder. Pese a ello, hubo iniciativas que durante más de cincuenta años estuvieron recordándole a la historiografía literaria peruana y boliviana que todavía no se había escrito uno de sus capítulos más importantes. En Bolivia, fueron Carlos Medinaceli, Carlos Salazar Mostajo, Guillermo Lora, Jaime Saenz, Blanca Wiethüchter y el equipo de investigación de Hacia una historia crítica de la literatura en Bolivia quienes primero advirtieron

ISterista Iberoamericana, Vol. LXXXI, Núm. 253, Octubre-Diciembre 2015, $989-1013$
ISSN 2154-4794 (Electrónico) 


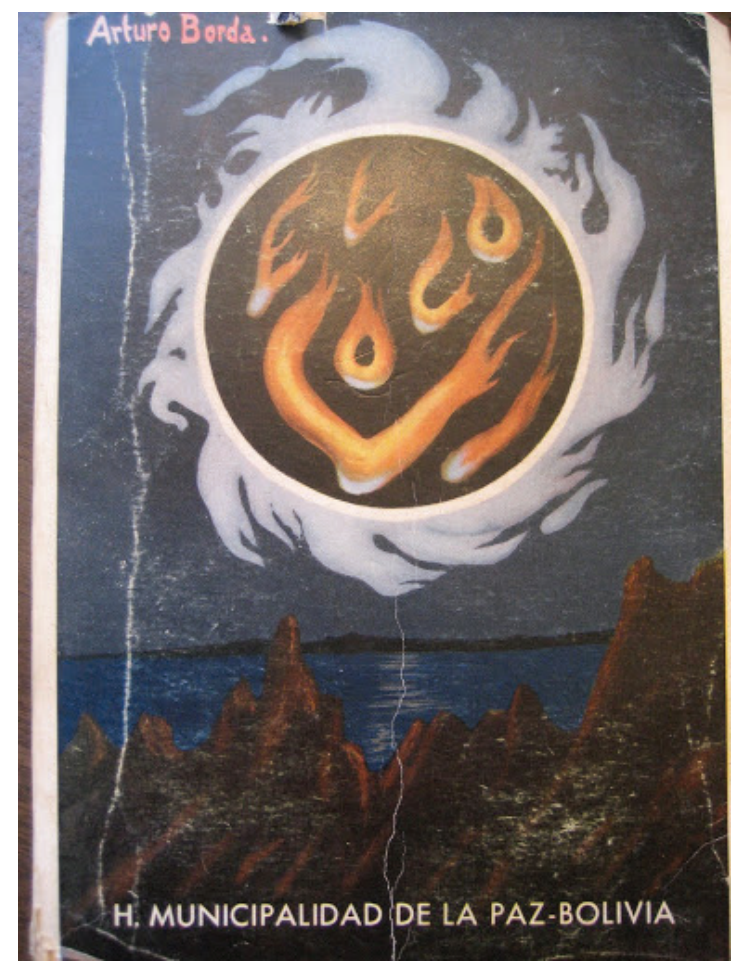

Portada de la primera edición de El Loco

La Paz: Honorable Municipalidad de la Paz-Bolivia, 1966

y teorizaron la importancia de Borda para la literatura boliviana. ${ }^{6}$ En la década de los cincuenta, Medinaceli, Díez de Medina y los integrantes de Gesta Bárbara ${ }^{7}$ llamaron la

${ }_{6}$ Uno de los miembros de ese equipo, Rodolfo Ortíz, está actualmente trabajando en una tesis doctoral sobre Borda que ofrecerá el primer estudio orgánico de su obra.

7 Gesta Bárbara fue el nombre del "aguerrido y combativo" grupo literario que Churata, cuando se llamaba Juan Cajal, formó en el Potosí de 1918 junto a Carlos Medinaceli, José Enrique Viaña, Armando Alba y otros jóvenes potosinos impregnados de bohemia modernista y con muy poco interés en la "cuestión social". En la historiografía boliviana, Gesta Bárbara ocupa el lugar del primer movimiento literario iconoclasta que se pensó como generación e imaginó la entrada del bárbaro al campo de la literatura. En un gesto de abierta rebeldía, sus integrantes reclamaron para sí el sobrenombre de bárbaros que se atrevían a escribir "en Potosí, a 4.140 metros de altura sobre el nivel de la vulgaridad” (Medinaceli 91). Entre 1918-1926, Gesta Bárbara publicó una revista del mismo nombre en la que Churata, pese a haber publicado únicamente un artículo (dedicado a González Prada y la efemérides potosina), desempeñó un indiscutible liderazgo intelectual.

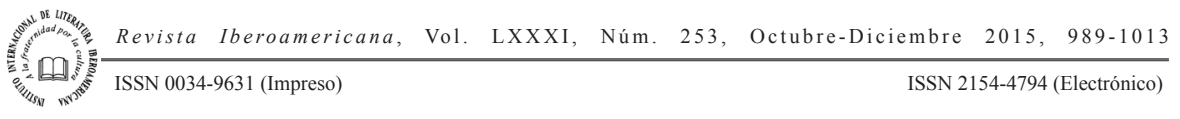


atención sobre la excepcionalidad del trabajo de Churata y su indiscutible contribución a la literatura latinoamericana, y a fines del siglo XX, Wiethüchter lo incluyó en la historia de la literatura boliviana. En el Perú, los escritores puneños siempre supieron que Churata estaba destinado a una gran atención en el futuro, pero desde la academia recién en la década de los setenta, con la publicación de Antología y valoración (1971) y la tesis de Omar Aramayo (Universidad Nacional del Altiplano, 1979), su obra empezó a ser estudiada. Cornejo Polar, sin duda el estudioso que más efectivamente ha incorporado en la academia la producción cultural de la región andina, sólo de pasada mencionó la obra de Churata como "uno de los grandes retos no asumidos por la crítica peruana" (140).

Recientemente, y en actos conmovedores, peruanos y bolivianos iniciaron el largo camino de repensar sus literaturas nacionales en diálogo con escritores que en vida fueron ignorados, marginados, y hasta exiliados de la República de las letras, en gran medida porque sus biografías y proyectos literarios antagonizaban con la imagen que del "escritor" y de la "literatura" tenían las clases medias y altas del Perú y la Bolivia de principios de siglo XX. La jornada vivida en el Congreso de la República del Perú el 3 de febrero de 2012 fue conmovedora porque sirvió para que todo un país saldara simbólicamente su mayor deuda literaria. Así lo entendió Estrella Peralta (hija de Churata), cuando en respuesta al congresista Yonhy Lescano Ancieta, que en nombre del Congreso de la República y del Estado Peruano pidió perdón a la memoria de Gamaliel Churata por habérsele maltratado y desterrado del Perú, lanzó palabras inolvidables:

Nunca en el Perú se ha dado este hecho tan singular y significativo. No hay tampoco precedentes que en América Latina, un Estado-nación soberano y democrático haya tenido la entereza y valentía de reivindicar a un escritor después de su muerte física. Es también la primera vez que el estado peruano pide disculpas, pide perdón a la memoria de un intelectual peruano, por haber sido agredido en vida, maltratado e injustamente desterrado durante más de treinta y dos años.

[...] Aunque no es el momento para hacer un recuento de los años de dolor humano y lucha contra la adversidad, creemos que Gamaliel Churata no mereció el trato que recibió desde adolescente de parte de una sociedad con mentalidad estrecha y colonial. Tampoco que haya sido subrogado de su función de bibliotecario y menos perseguido por una dictadura que ahora viene a ser una ignominia para la historia del Perú.

[...] Aunque Manuel González Prada, César Vallejo, José Carlos Mariátegui, Clorinda Mato de Turner, Adela Montesinos, Magda Portal, Ciro Alegría, Carlos Oquendo de Amat, Alejandro Romualdo, sobre todo Javier Heraud y José María Arguedas, para no mencionar más ilustres escritores peruanos, jamás recibieron un trato adecuado en vida ni después de muertos, el Estado Peruano jamás les pidió perdón por las atrocidades y abusos cometidos contra ellos. Pero con Gamaliel Churata y de esta manera, se inicia una revisión de la historia, del imaginario colectivo, para así establecer un distinto tiempo histórico. Ese hecho nos llena a nosotros de sentimientos que lindan entre

Revista Iberoamericana, Vol. LXXXI, Núm. 253, Octubre-Diciembre 2015, 989-1013 
el agradecimiento, el orgullo, recuerdos de infancia y la infinita ternura de nuestro querido e inolvidable padre.

[...] Que un Estado democrático, que un Congreso soberano elegido por el pueblo peruano reivindique a Gamaliel Churata, es también reivindicar a escritores, artistas y poetas contemporáneos, a sus condiscípulos como Alejandro Peralta, Diego Kunurana, Mateo Jaika, Carlos Dante Nava, Aurelio Martínez, Inocencio Mamani, Eustaquio Aweranca. Especialmente a Alberto Mostajo, a su amigo Manuel Z. Camacho, a Teodomiro Gutiérrez Cueva "Rumi maqui" y a Francisco Chuquihuanca Ayulo. Todos ellos junto con Gamaliel Churata, le dieron al Perú, una fisonomía distinta a una imposición intelectual francamente colonial desde Lima. (Estrella Peralta s.p.)

Igualmente conmovedor fue que en 2009, cuando el Ministerio de Culturas del Estado Plurinacional de Bolivia encargó a un equipo de expertos de la Universidad Mayor de San Andrés y de la Universidad Católica Boliviana la elaboración de un canon literario que reuniera 15 novelas representativas de la literatura boliviana, $E l$ loco haya obtenido un lugar en esa selección. Tres años después, el 28 de diciembre de 2012, el Ministerio de Culturas entregó al país una colección de las "15 novelas fundamentales" de la literatura boliviana que finalmente sacó a El loco del olvidadero, proporcionando al lector actual la oportunidad de apreciar la excepcionalidad de un texto que durante todo el siglo XX había pasado incomprendido y (con contadas excepciones) proscrito de la crítica literaria.

Parafraseando una expresión de Bosshard en referencia al libro de Churata, es posible afirmar que tanto en el caso de El pez de oro como en el de El loco, estemos frente a textos que asustan. Asusta que su escritura vanguardista remita a 1902, en el caso de Borda, y aproximadamente a 1907, en el de Churata, cuando ni Marinetti ni Huidobro ni Breton habían abierto las puertas de la vanguardia. Asusta también la insoportable irreverencia con que denuncian el "pongueaje intelectual" que postergaba cualquier posibilidad de dignidad histórica, estética y social en América, y su resistencia a parámetros artísticos convencionales. Estos libros, ya lo dije, no son necesariamente novelas, tampoco diarios, poesía, teatro ni ensayo, pero poseen rasgos característicos de esos géneros literarios, sometidos al "nerviosismo artístico" de escritores interesados en captar formas estéticas propias de las culturas andinas, en el caso de Churata, y de las marginalidades urbano-populares, en el caso de Borda. Como si esto no fuera suficiente para exasperar al lector convencional, ensayan una escritura distinta a todo lo que se había ensayado antes en Perú y Bolivia. Son texos plurilingües (castellano-aymara, quechua, quechuaymara), fragmentados, carentes de "aventura de héroe", sin pretensión de obra acabada, porfiadamente descolonizadores y críticos de las desigualdades y racismos que perpetraba una modernidad excluyente. Con esas características, entraron de lleno en la categoría de extravagantes e inaceptables para el buen gusto. Hoy día, en la era de los movimientos sociales y del ascenso indígena al poder político, esas "extravagancias"

Revista Iberoamericana, Vol. LXXXI, Núm. 253, Octubre-Diciembre 2015, 989-1013 


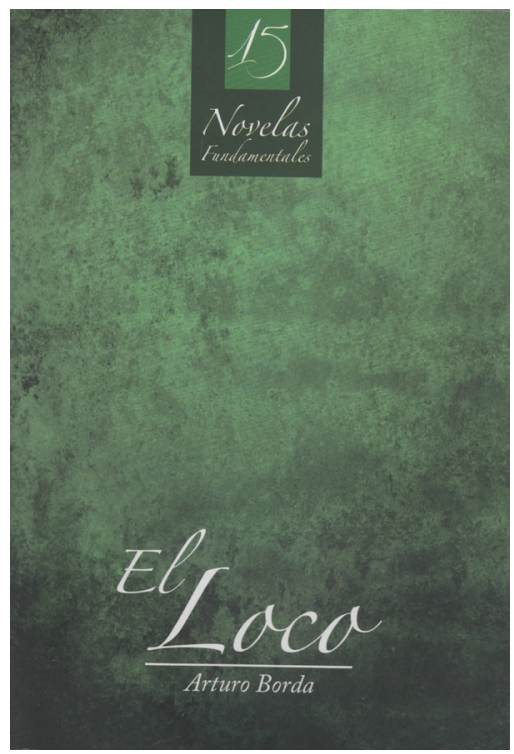

Portada de la segunda edición de El Loco

La Paz: Ministerio de Culturas y Plural Editores, 2012

han entrado al canon literario y están generando importantes reorientaciones no sólo en el estudio de la dinámica literaria peruana y boliviana, sino también del evento vanguardista en América Latina. La crítica actual ha de tener que tomar en cuenta que en 2012 El Loco fue incluido en el canon literario boliviano, reeditado, y distribuido de manera gratuita en colegios y universidades del país, convertido ya en lectura obligatoria en el curriculum plurinacional. De igual manera, se ha de tener que considerar que entre 2011 y 2014, después de casi sesenta años de silencio editorial, se publicaron dos reediciones críticas de El pez de oro (la de José Luis Ayala, que inauguró la Biblioteca Gamaliel Churata, y la de Helena Usandizaga, bajo el sello de la editorial Cátedra), varios textos inéditos, ${ }^{8}$ y más de un centenar de artículos dedicados a la investigación de la obra churatiana, además de congresos, conferencias, simposios y blogs que en

8 Hay que mencionar la publicación, en 2010, de La resurrección de los muertos, preparada por Riccardo Badini. En una de sus últimas intervenciones públicas, Churata indicó que su obra estaba compuesta por 18 volúmenes, de los cuales El pez de oro era el primero, seguido precisamente por La resurrección de los muertos. También importante fue la publicación de una conferencia titulada "Dialéctica del realismo psíquico", donde Churata proporciona claves de lectura para El pez de oro. Esta conferencia, también publicada por Badini, apareció en Simbología de El Pez de Oro, con comentarios suyos y de José Luis Ayala. Actualmente está en preparación un volumen que, bajo el cuidado de Badini, reúne la poesía inédita de Churata.

Revista Iberoamericana, Vo1. LXXXI, Núm. 253, Octubre-Diciembre 2015, 989-1013 
el momento actual conforman ya una bibliografía inabarcable (como sugirió Espezúa Salmón) y un campo de estudio visibilizado no sólo en la academia latinoamericana, sino también en la norteamericana, europea y asiática. Pero es el lugar y el cariño que Churata se ha ganado entre los escritores jóvenes del sur peruano y el altiplano boliviano el factor que más efectivamente ha de darle definición al impacto que el proyecto de El pez de oro pueda tener en el futuro de las colectividades andinas. En la ciudad de El Alto, por ejemplo, ha surgido un colectivo literario integrado por jóvenes aymaras autoidentificados como Yerba Mala. El colectivo propone una "estética cartonera" que además de reciclar cartón para, en esa basura, escribir sus textos, busca que un "reciclaje de la conciencia" intervenga en el lector cuando éste entra en contacto con esa "basura". Lo conmovedor es que Churata, para estos jóvenes cartoneros, constituye un punto de referencia fundamental. Leemos, en uno de sus manifiestos:

(La yerba mala crece en rincones de capillas). Por este mismo motivo y reutilizando la piedra angular esculpida por Gamaliel Churata - ese faro que hoy resucita -, debemos lanzar la premisa: Anticipamos el amanecer a lo oscuro (con plena conciencia de que uno es imposible sin el otro) y, centralmente, parados sobre la propia experiencia, confiamos nuestra íntima fuerza interior que predica: en Yerba Mala nadie cree en la Muerte. ("Yerba Mala Cartonera" 132)

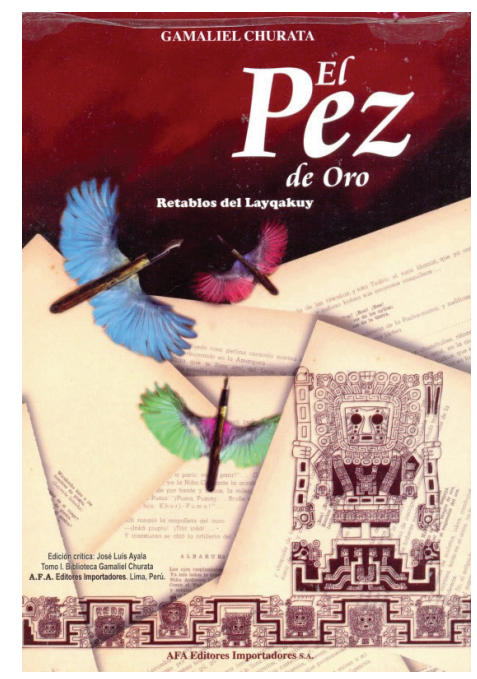

Portada de la edición crítica preparada por José Luis Ayala

(AFA Editores, 2011)

Revista Iberoamericana, Vol. LXXXI, Núm. 253, Octubre-Diciembre 2015, 989-1013 


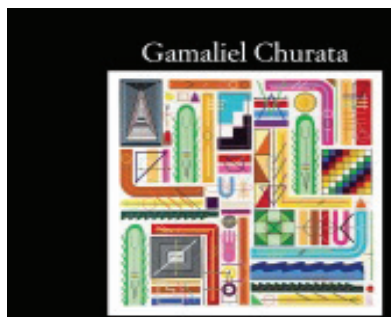

El pez de oro

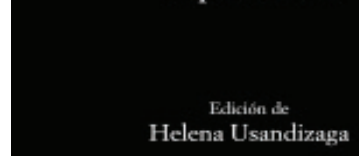

CATEDRA

Letras Hipinicus

Portada de la edición crítica preparada por Helena Usandizaga

(Cátedra, 2012)

Ante hechos tan singulares, uno se pregunta cómo ha sido posible que sucedieran, pero además se asombra por la coyuntura que los rodea, pues al mismo tiempo emergen del olvido escritores definitivamente atípicos y sin embargo emparentados entre sí. Bolivia, el país donde Borda vivió toda su vida y Churata un exilio de 32 años tuvo sin duda un rol determinante en este parentesco, pero mucho más importante fue la porfía con la que ambos concibieron un vanguardismo en el que entraban en juego "todas las diagonales de la vida moderna", incluida la feroz subalternización del indio y de las marginalidades andinas urbano-populares. Una carta de Churata a Mariátegui, fechada en Puno el 27 de noviembre de 1926, ilustra magníficamente lo que estoy tratando de decir:

Querido compañero Mariátegui:

$[\ldots]$

Cuando Ud. probablemente se nutría de selecta literatura, lo que sin duda le ha procurado esa admirable pureza y agilidad de su expresión, yo vomitaba (siempre sólo podré hacer eso) toda la dinamita que la esclavitud del indio producía en mis nervios. A los quince años desafiaba a duelo a un gamonal, a causa de los indios, y a los diecisiete me encarcelaban a causa de haber insultado el gobierno de Benavides. Soy, pues, orgánicamente, un vanguradista (en verdad que la palabra también me ha cansado). (Mariategui, Correspondencia 193)

Revista Iberoamericana, Vol. LXXXI, Núm. 253, Octubre-Diciembre 2015, 989-1013 


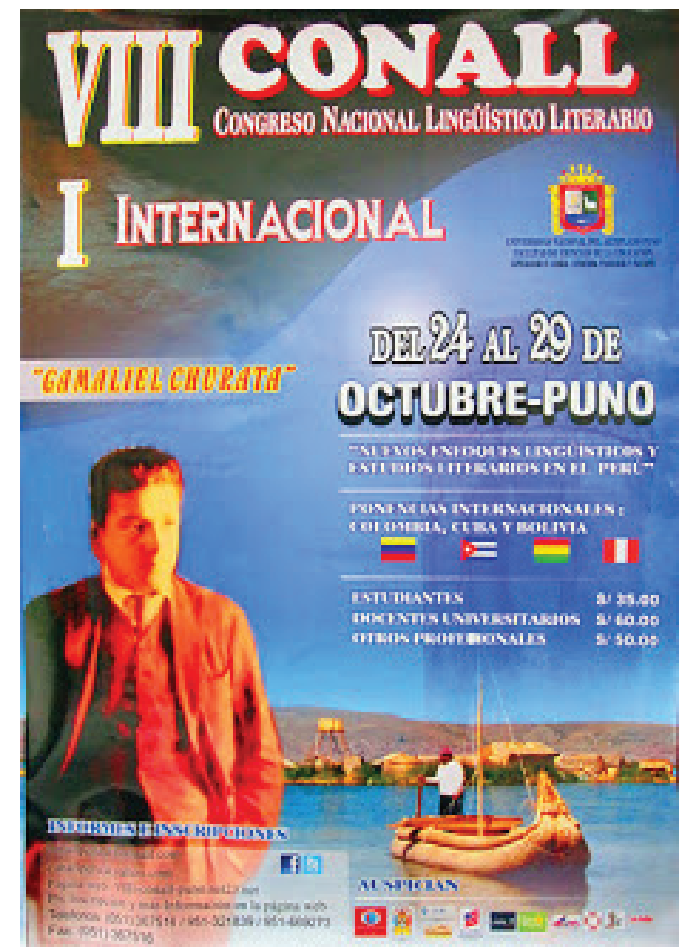

VIII Congreso Nacional Lingüístico-Literario (CONALL) "Gamaliel Churata"

24-29 de octubre, 2011

Universidad Nacional del Altiplano

Participantes: Jorge O. Reynoso Díaz, Rodolfo Cerrón Palomino, Omar Aramayo, Dorian Espezúa, José Luis Ayala, Mario Guevara, Martha E. Varon Paez (Colombia), Ingrid Hernandez Moya (Cuba), Crescencio Chamani Mareño y Alex Chaman Portugal (Bolivia), entre otros.

Borda, sin necesariamente canalizar su escritura a través de la problemática indígena, cuestionó vehementemente la condición colonizada del indio y de las subalternidades sociales en la Bolivia de mediados de siglo XX. Como Churata, también "vomitó" indignación, y en su caso el vómito dio forma a lo que en otros trabajos me he atrevido a llamar el útimo ismo vanguardista: el demolicionismo, que además de la demolición de una sociedad y de una cultura colonizada, proponía la demolición de la mansedumbre de los subalternos: 
Lo que en esto [en una situación colonizada] hay de insoportable es la vil mansedumbre de los subalternos que se hacen sobajear como a perros muertos de hambre. ¿Cuándo reventará la dignidad humana? ¿Cuándo se sublevará la humillación? (El loco I: 79)

El producto de tan desafiantes intervenciones fueron propuestas literarias que en su momento ni la intelectualidad peruana ni la boliviana pudieron digerir. "Beligerancias", diría Churata, que se tradujeron en pesadilla para el lector de mediados de siglo XX y enorme desafío para el del XXI, porque obligan a pensar fuera de la razón moderna, fuera de los valores universales y fuera del marco conceptual de las literaturas nacionales en las que no encontraban cabida o de las que eran proscritas. Admitir que estas obras caían fuera de espacios nacionales y activaban circuitos culturales alternativos a los que toleraba el Estado-nación es tal vez uno de los mayores desafíos que el trabajo de Borda y Churata le plantea a la reflexión crítica actual. Para apreciar esta excepcionalidad teórica he de volver a las palabras de Estrella Peralta y subrayar que cuando una nación pide disculpas a la memoria de un escritor por haberlo "desterrado injustamente durante más de treinta y dos años", nada garantiza que ese escritor se reintegre armónicamente a la tradición literaria de la que fue desterrado. En un gesto irónico, esos treinta y dos años de destierro problematizan la dinámica del perdón. No son negociables. En treinta y dos años de destierro, Churata se desvinculó del relato moderno peruano y de la "literatura nacional" que de él derivaba, al mismo tiempo que Borda, desde la marginalidad en que vivió, escribió, pintó y murió, se desvinculaba de la modernidad boliviana y de su "cultura nacional". ¿Cómo entonces integrarlos, sin violencia, a marcos nacionales que ellos mismos cuestionaron y derrumbaron? ¿No será que ni siquiera desde el arrepentimiento estamos a la altura de los desafíos que estos escritores le plantearon al proceso literario peruano y boliviano? Una de las mayores interpelaciones que Churata le hizo a la literatura peruana (y por extensión a la latinoamericana) fue enfrentarla a su falta de ajayu, ${ }^{9}$ que la convertía en una literatura vacía de "alma nacional". La nacionalidad, en palabras de Churata "supone población, población arguye mayorías" y "si las mayorías constituyen nación por naturaleza [...] nadie puede gobernar sin ellas" (915), mucho menos postular una literatura nacional al margen de ellas. Continúa Churata:

es de necesidad sostener que cuando un país se rige sometido a sus minorías, ese país carece de alma nacional; y nada menos admisible que patria sin alma...

Por tanto, Runa-Hakhes, patria no es colonia.

9 Ajayu, en lengua aymara, se traduce aproximativamente como "Ánima, espíritu, alma” de las cosas y seres vivientes. Una literatura, en semántica aymara, puede por tanto tener ajayu, de la misma manera que un ser humano, un animal, un río o una montaña.

Revista Iberoamericana, Vol. LXXXI, Núm. 253, Octubre-Diciembre 2015, 989-1013 
Escarpada o roma, lisa o aguda, si un país tiene alma nacional ella es alma de las mayorías. Alma colectiva: naya. Corporación multánime en que las unidades encuentran la unidad.

La literatura americana es portuaria y de ventolina, a merced de las incitaciones de los meridianos mentales del viejo mundo, y ya bulevardiza, estepiza, niponiza, heleniza, y siempre en criollismo, nativismo, decadentismo vanguardismo, realismo, naturalismo, acaba excéntrica, con desasimiento que no sea en el pintoricismo episódico y vacuo, de la coordenada india. Excluyo naturalmente de este juicio al vanguardismo del Titikaka (el hecho más curioso e insólito de la literatura del Perú en los últimos tiempos, según L.A. Sánchez), que de "vanguardista", en el sentido europeo, tenía pocas, o ninguna, condescendencias.

[...] No es un reproche [...] a los excelsos poetas hispanoamericanos que son lustre de la hispana literatura, pero de esos camafeos brilladores está empredrado nuestro andrajo [...]. Si hacemos literatura social, la hacemos moscovita; y por ahí es que entendemos la tragedia del indio. Y tanto que esta literatura por lo general la hacen revolucionarios... decentes.

Al Diablo con la porra. No hay literatura americana porque no hay americanos. ( $E l$ pez de oro 916, 170-72)

La posibilidad de una literatura nacional, en percepción de Churata, no dependía del virtuosismo de escritores geniales, ni del empuje de ateneos o academias, ni de una disposición a la modernidad de internacionalidades cosmopolitas, sino más bien de una capacidad colectiva para engendrar literatura "desde sí mismo". La realidad del Perú le informaba que la llamada "literatura peruana" había sido engendrada "fuera de sí misma". La habían engendrado, sistematizado y canonizado, sus minorías, y lo habían hecho desde una lengua y desde una estética que no interpretaban la sensibilidad de las mayorías. La enorme importancia que Churata le da a los idiomas andinos aymara y quechua deriva de estas preocupaciones y no de un rechazo irracional del idioma español o de un desconocimiento de la composición multiétnica de los países andinos. Lo que Churata está proponiendo es que en terreno artístico "nadie engendra fuera de sí mismo", y como caso ejemplar trae a El Greco, señalando que únicamente aferrado al ñuño de Castilla pudo haber parido El Entierro del Conde de Orgaz. ¿Algo más español? Ni Loyola; ni Felipe II (El pez de oro 207).

Esos rostros enjutos, estoicos e individualizados que admiramos en El Entierro del Conde de Orgaz son España porque interpretan a cabalidad el "ego" hispano del siglo XVI, fruto del estoicismo de Séneca y la conciencia individualista renacentista. Si la grandeza de El Greco estriba en haber captado magistralmente el "ego" del pueblo del que era hijo, la percepción que Churata tuvo del proceso estético es válida: cuando más intensamente se expresa la belleza (que nuestro escritor prefiere llamar

Revista Iberoamericana, Vol. LXXXI, Núm. 253, Octubre-Diciembre 2015, 989-1013 
"hermosura") es cuando llega amarrada a su "ego", entendiendo por "ego" no una reducción esencialista a la propia vida, sino más bien una posibilidad de constitución intersubjetiva. La crítica que Churata le hace a los artistas y escritores de su época es que con contadas excepciones (Guamán Poma en el siglo XVII, Jorge Icaza, José María Arguedas, Cardoza y Aragón en el XX), pretenden producir belleza, arte, y literatura, aferrados a "egos" extranjeros. Contra estos "histéricos fuera de sí" articuló esa contramarcha cultural denominada "vanguardismo del Titikaka". Detenerme en el estudio de esta intervención vanguardista excedería los límites de este trabajo, por lo que me limitaré a una discusión muy general de sus coordenadas estéticas. ${ }^{10}$

Estamos ante un vanguardismo que desentendiéndose de los ismos, buscó expresar el "ego" andino, entendiendo que se trataba de un "ego" distinto al hispano -sin que "distinto" conlleve la insinuación de "mejor". La realidad de los ayllus de Puno en sus enfrentamientos con el gamonalismo y la convivencia con intelectuales indígenas integrantes del ayllu Orkopata, indicaban que ni enjuto, ni estoico, ni individualizado, el "ego" andino tendía a ser colectivo y definitivamente no antropocéntrico, porque estaba inmerso en una interrelacionalidad con la Tierra animada y los animales y geografías que la cohabitaban. El artista andino, si quería captar ese "ego", debía en primer lugar sintonzarse con él.

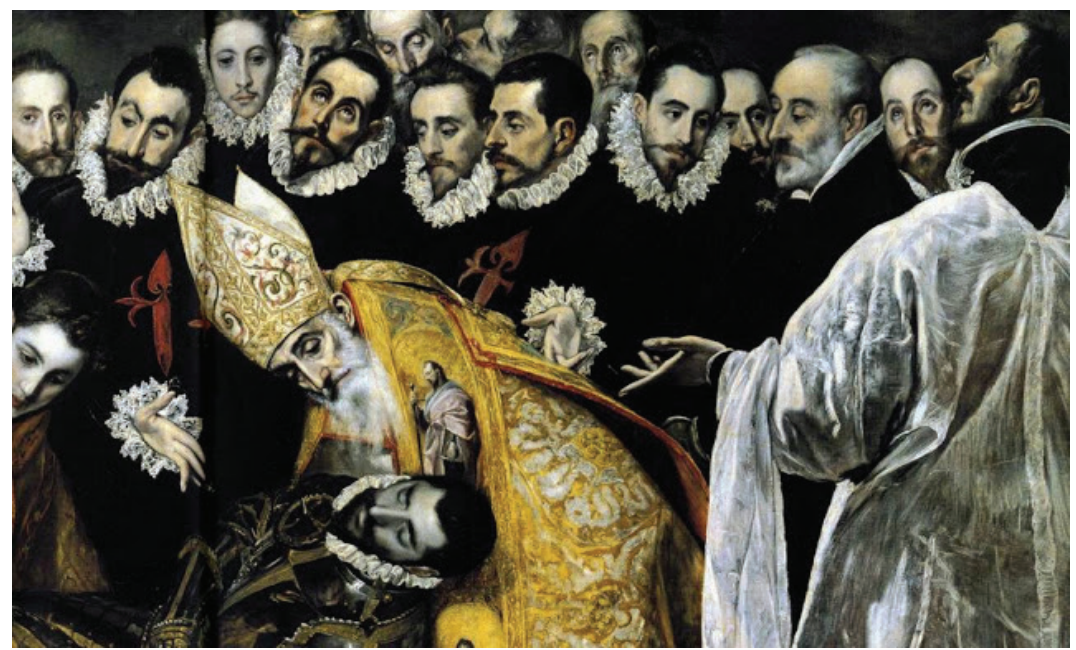

Detalle de El Entierro del Conde de Orgaz (1586-1588)

Oleo, $15^{\circ} 9^{\prime \prime} \times 11^{\prime} 10^{\prime \prime}$ ( $\left.4.8 \mathrm{~m} \times 3.6 \mathrm{~m}\right)$

Museo del Prado

${ }^{10}$ Un estudio extenso del vanguardismo del Titikaka puede verse en mi libro La vanguardia plebeya del Titikaka. Gamaliel Churata y otras beligerancias estéticas en los Andes (2015).

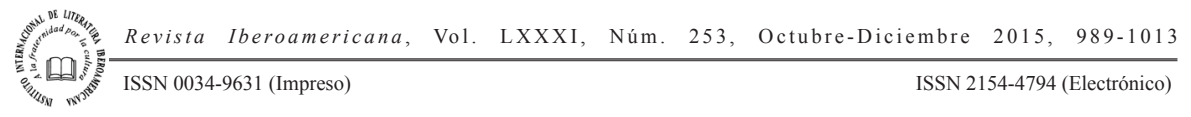


Churata sabía que pensar en estos términos polemizaba con la estética clásica, que en su versión platónica concibe la belleza como una Idea con valor universal a la que el artista se siente llamado a imitar. Tributaria de la máquina clásica, la literatura peruana imitaba clasicismo, romanticismo, modernismo, y cuando apostaba al indigenismo incurría en deslealtades que subalternizaban, patronizaban, idealizaban o politizaban las culturas andinas con parámetros e intereses ajenos a ellas. La lección de estética que nos obsequia Churata interpela la estética clásica en su momento constitutivo, es decir, en su formulación platónica. Escuchemos a Churata en su primera interpelación al discípulo de Sócrates, al que se dirige con el vocablo latino Plato:

El único mandamiento de la belleza viva: ¡engendrar!

¿Entiendes, Plato? Para el americano de América: ¡engendrar! ¡engendrar!

Engendrar hasta la profundidad del Tawantinsuyu. (El pez de oro 213$)^{11}$

Llama la atención que para referirse a la disciplina que habla de lo bello, Churata elige un verbo de acción (engendrar) que le permite vincular las zonas del intelecto con las zonas de reproducción de la vida. Postula Churata que es en la germinación, en el rebrote de la vida, donde se expresa la belleza, y que no existe momento más "germinal" que el marcado por el grito del recién nacido. Ese "primer burbujeo" emparenta al que ha nacido a la entraña que le dio vida. De aquí que desde una perspectiva andina el ser humano no está sometido a las fatalidades heideggerianas. Más que "arrojado a un mundo que lo convertirá en un ser desolado", ${ }^{12}$ el sujeto andino está, desde su nacimiento, emparentado con un mundo que lo recibe, lo cría y lo integra social y económicamente a la comunidad del ayllu. Propone Churata que nunca es más conmovedora la "hermosura" que cuando su creador la forja aferrado(a) al nuño que le dio vida y lo emparentó con el mundo. Esta argumentación le permite postular que

11 En El pez de oro encontramos varias interpelaciones directas a Platón y cada una desafía distintos aspectos de su pensamiento. En su mayoría, estas interpelaciones están formuladas desde estructuras lógicas similares a la que acabo de citar y siempre concluyen preguntando “¿Entiendes, Plato?” Una serie distinta de interpelaciones ahonda en el desacuerdo, calibrando el efecto que podría estar causando su discurso (“¿Qué? ¿Te hirieron; lloras, Plato?...”) o exigiendo respuestas (“¡Contesta Plato!”).

12 En El ser y el tiempo (1927) Heidegger abordó la conflictiva pregunta por el sentido del ser humano moderno (Dasein) desde un pensamiento anti-metafísico, es decir, despojado de ideas abstractas y más bien anclado en la realidad del mundo, de ahí la idea de ser-en-el-mundo. Ese mundo, para Heidedegger, representa la modernidad de nuestra época, y se diferencia del antiguo no tanto por una pérdida de religiosidad (confianza en un ente supremo llamado Dios), sino porque a él el ser humano no llega en términos armoniosos, más bien cae en él. Es arrojado a él, y esa caída lo convierte en un "ser desolado" cuyo estado de ánimo vital es la angustia. Para Heidegger el drama del ser humano moderno no radica en pensar que puede vivir sin Dios, sino más bien en sentirse Dios en un mundo inhóspito, desfamiliarizado, que nunca se convertirá en "su casa" y en el que la angustia se ha convertido en su modo de ser más inmediato, quedando oculta su posibilidad más propia: la de ser libre, la de "elegirse".

Revista Iberoamericana, Vol. LXXXI, Núm. 253, Octubre-Diciembre 2015, 989-1013 ISSN 0034-9631 (Impreso)

ISSN 2154-4794 (Electrónico) 
con la notable excepción de José María Arguedas y los vanguardistas del Titikaka, la literatura peruana no creaba, no engendraba, precisamente por estar sometida a minorías intelectuales aferradas a nuños y parentescos extranjeros. Llamarle "literatura nacional" al trabajo que producían esas minorías era equivocar el camino. Por eso el proyecto estético de El pez de oro se desvincula de "esa" literatura y la desenmascara a escala continental:

... afirmamos la vigencia de una Literatura Americana no por sus raíces americanas sino por el cosmopolitismo oceánico que rompe todo pudor y candidez a la expresión estética. Eso nuestro americanismo... Que sea, si así lo impone el determinismo colonial. Pero ese americanismo no es americano.

[...] si América ha perdido toda esperanza de expresarse en un idioma con patria, más que ocioso, es cretino, hablar de Literatura Americana. Debe hablarse de Literatura Española de América, y con más propiedad de Literatura Española a secas; que si en España se habla de Literatura Española de Vascos; Catalanes, Aragoneses, es porque hay vascos, catalanes, aragoneses, que piensan y sienten, y producen, en lenguas aborígenes, y en temple agonal, que diría el hispano centrífugo que fue don Miguel de Unamuno. (El pez de oro 167 y 183)

En contraste a esos vascos, catalanes y aragoneses que piensan, sienten y producen literatura española desde sí mismos, Churata denuncia que en el sur peruano los aymaras y quechuas no sólo habían sido expulsados de la República de la literatura, sino que además sus contribuciones a la dinámica cultural del país habían sido saboteadas:

Nadie vio en el mugriento español de Huaman Poma, o Tupak Khatari, la dialéctica de una estética; ningún crítico tabuló la chaskhadera; se la dejó para los espectáculos del Thantakhatu; jamás se pensó en extraerla de las zonas plebeyas a que el alma americana fue confinada. (El pez de oro 184$)^{13}$

De este pasaje de El pez de oro deriva toda una reflexión en torno a la lengua que culmina con la desafiante propuesta de que "El español tendrá que hibridarse rindiendo parias a Huaman Poma" para que pueda hablarse de literatura peruana nacional ( $E l$ pez de oro 185). Este aspecto tan polémico y provocativo del pensamiento de Churata cobra particular relevancia en el momento actual, cuando el trabajo de intelectuales indígenas que empiezan a circular en la política y la academia internacional suscita descalificaciones porque sus autores "no hablan bien español" o porque "sus textos están mal escritos", publicados en "editoriales menores", o porque son "esencialistas,

13 Nótese la opción de Churata por escribir "Huaman Poma" y no "Guamán Poma". Para una lectura de las relaciones entre El pez de oro y la obra de Guamán Poma con énfasis en la metafórica del tejido, ver la colaboración de Meritxell Hernando Marsal en este volumen.

Revista Iberoamericana, Vo1. LXXXI, Núm. 253, Octubre-Diciembre 2015, 989-1013 
mileraristas, mesiánicos", lo que equivale a desautorizarlos por retardatarios y torpes para estar a la altura del tempo que dictaminan los centros de control mundial de la cultura. La figura de Tupak Katari en el discurso de Churata ofrece una magnífica ocasión para reflexionar sobre estas violencias. ¿Por qué, junto a Guamán, Churata pone a Tupak Katari? Habría sido más lógica una referencia a Tupac Amaru o a cualquiera de los líderes tupamaristas de 1781. Para entender la lógica que guía su razonamiento, vale la pena abrir un paréntesis histórico y precisar la figura de Tupak Katari.

Estamos hablando del guerrero aymara que después de la muerte de Tupac Amaru, en mayo de 1781, lideró desde La Paz la facción más radical de la Gran Rebelión de 1781, que por intervención suya adquirió comportamiento panandino al desplazarse desde el Cusco y Puno hasta Chayanta, en el norte de Potosí, y La Paz. Los historiadores ya han señalado que a diferencia de José Gabriel Condorcanqui, Tupac Katari era un indio pobre, sin vínculos con nobleza indígena alguna, y con un programa político distinto al tupamarista. En Cuando sólo reinasen los indios. La política aymara en la era de la insurgencia (2006), Sinclair Thomson subraya que al concebir la posibilidad de una inserción razonable en la sociedad colonial vía alianzas con sectores criollos, Tupac Amaru actuaba desde una lógica comprensible para las élites políticas criollas. Katari, en cambio, resultaba absolutamente incomprensible, porque accionaba desde un militarismo milenarista y etnocentrista que con un ejército de 40,000 indios buscaba la demolición de la sociedad colonial en su conjunto. Representaba, en este sentido, un "desborde" indígena que tanto peninsulares como criollos sentían la urgencia de liquidar. Esa radicalidad, hoy día vigente en los ayllus más rebeldes del altiplano boliviano, hizo que Tupac Katari "nunca haya podido encajar cabalmente en el panteón nacionalista boliviano, ni siquiera como precursor de la independencia" (Thomson 223). La historiografía boliviana de mediados de siglo XX tuvo enormes reparos a la hora de "absorber" la figura histórica de Tupac Katari. Ese ideólogo del nacionalismo revolucionario que fue Carlos Montenegro, por ejemplo, optó por ignorar su intervención en el conflicto libertario, mientras otros historiadores lo identificaron como artífice de una "guerra de razas" y por tanto enemigo de la nación boliviana (ver Finot e Imaña Castro). Esas lecturas equivocadas impidieron, como sugiere Thomson, que la figura de Tupac Katari fuera integrada al imaginario político nacionalista porque algo indicaba que era incompatible con él.

Esta breve contextualización permite conjeturar que cuando Churata actualiza en su discurso las figuras de Huamán y Tupac Khatari, lo hace precisamente al margen de intereses nacionales que harían de Guamán Poma un peruano y de Tupak Katari un boliviano. Aquí lo relevante es llamar la atención sobre la conciencia crítica y la voluntad descolonizadora que atraviesa la escritura de Guamán y Katari, lingüísticamente expresadas en "el mugriento español" con que ambos se expresaron. Tengo dos ejemplos que dan cuenta de mi argumento. El primero está tomado del capítulo de las “Ciudades y villas" de la Nueva corónica y buen gobierno. En las páginas dedicadas a

Revista Iberoamericana, Vol. LXXXI, Núm. 253, Octubre-Diciembre 2015, 989-1013 
la Villa Imperial de Potosí, encontramos un texto que excediendo las expectativas de la descripción urbana, nos entrega una elaborada reflexión crítica de la condición colonial, escrita en un lenguaje que ni la intelectualidad del siglo XVII ni la historiografía del XX pudieron reconocer como castellano:

La Villa Rica Enpereal de Potocchi. Por la dicha mina es Castilla, Roma es Roma, el papa es papa y el rrey es monarca del mundo. Y la santa madre yglecia es defendida y nuestra santa fe guardada por los quatro rreys de las Yndias y por el enperador Ynga. Agora lo podera el papa de Roma y nuestro señor rrey don Phelipe el terzero. (1057)

Esta descripción de la Villa Imperial establece que sin la existencia de la minería de Potosí, la modernidad del siglo XVII habría sido simplemente impensable. Dicho de otra manera, el avance ibérico en América necesitaba la subalternización indígena para garantizar su funcionamiento. Lúcida historiografía la que estaba inaugurando Guamán, pero el "mugriento español" que la articulaba y el etnocentrismo europeo de la historiografía moderna impidieron reconocerla como un momento constitutivo del pensamiento crítico americano. Mi segundo ejemplo está tomado de una de las cartas que Katari le escribió al Corregidor Sebastián Segurola la víspera del cerco de La Paz, cuando su ejército de 40.000 indios hacía temblar al criollaje paceño con un proyecto político desvinculado ya de la aristocracia indígena tupamarista (que proponía una revolución "para romper con el colonialismo y modernizar al país") y más bien abocado a "transformar" los cimientos del mundo, entendiendo que una modificación (Pachacuti) del guión colonial era posible (Flores Galindo 143). Escribe Tupac Katari:

Y así Cristianos VV quieren á malas mañana lo verán con el favor de Dios, ya les tengo
por donde pegar avance, y así no hay mas remedio que tenga, si VV se porfían más;
no hay ni para tres horas con el favor de Dios para mis soldados, le dice acaban sin
duda, y así no hay más remedio que tengan los que tuvieren las armas, no será caso
para mí con el favor de Dios, y sepan han de volver por tierra y polvo, y a ver cual
nos ayudará de Dios y cual seremos hombres de carajos, y así este es de lo alto. [...]
y que tenga muy presente esta mi advertencia para que en adelante si despreciando
esto executase a lo contrario, se volvera todo en ceniza [...] oy 7 de abril de 1781 .
Que Yó S. Virrey Puma-Catari. ("Diario de los sucesos del cerco de la ciudad de La
Paz..." 194-195)

Sin excepción, la historiografía de la época (y en gran medida la actual) percibió esta carta como "bárbara", "incoherente" y producto de una mente desquiciada, sin siquiera plantearse la posibilidad de que en ella pudiera estar formulada la lógica con la que actuaba Katari. Esa iniciativa la toma Churata cuando en las primeras páginas de El pez de oro se convierte en el primer interlocutor intelectual de Guamán Poma y

Revista Iberoamericana, Vol. LXXXI, Núm. 253, Octubre-Diciembre 2015, 989-1013 


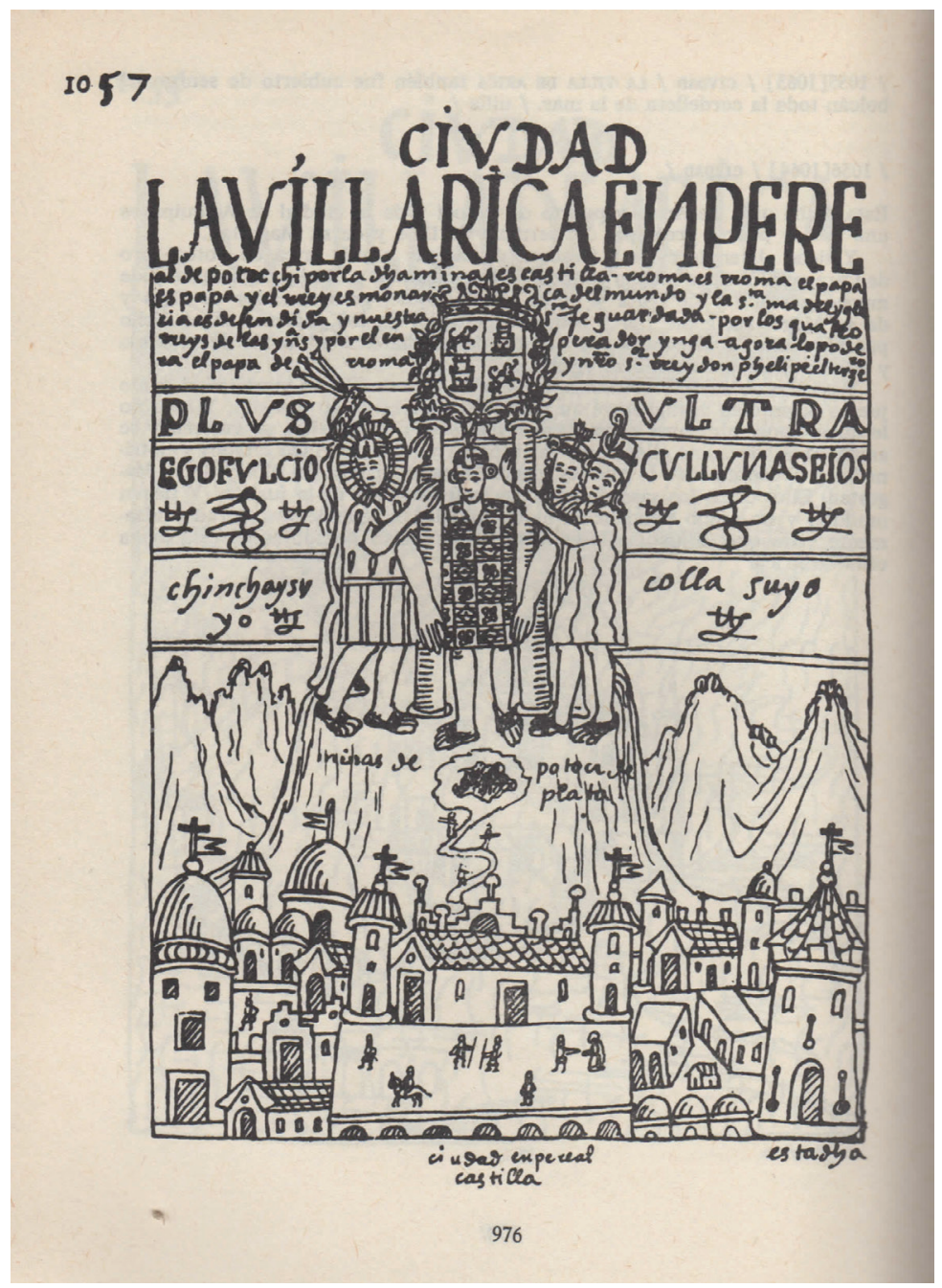

Tupac Katari y percibe en su "mugriento español" la dialéctica de una estética. (El pez de oro 184). Enmendado el error histórico, propone la "ortografía bárbara y plebeya" de Guamán Poma y Tupac Katari como momento constitutivo de esa beligerancia vanguardista que arrancó en Puno en 1926, cuyos integrantes más radicales vivieron “el complejo indigenista" (ese conjunto de emociones e ideas reprimidas en torno al indio) con la obsesión de "no interpretar al indio, sino expresarlo" (Churata, "Conferencia" 65-66). Jorge Basadre, Luis Alberto Sánchez, Antero Peralta, Luis Valcárcel, Uriel

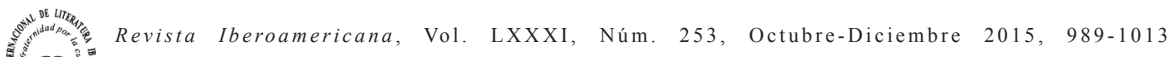
ISSN 0034-9631 (Impreso) 
García, e incluso Mariátegui, vivieron el mismo "complejo", pero con la obsesión de interpretar, representar, reivindicar y modernizar al indio, no de fundir intereses con él. Churata entendió perfectamente esa diferencia, pero no llegó a plantear que el indigenismo que se había gestado en Puno ya no era, en rigor, "indigenismo". Lo que sí le quedó claro fue que en Puno "surgió un movimiento vanguardista de raíz india" y

... nació la generación más brillante de la historia indigenista [...]. Todos estos hombres tenían una sola obsesión: no interpretar al indio, sino expresarlo. Eso quiere decir que nosotros hicimos una literatura porque vivíamos el complejo indigenista de nuestro pueblo. [...] Allí, en Orcopata, vivíamos, pensábamos y escribíamos con los indios y en indio. De allí el indigenismo que nosotros propugnamos no ha sido comprendido. (“Conferencia” 65-66, énfasis mío)

La inédita experiencia de escribir con los indios y en indio fue posible porque en el liderazgo del ayllu-Orkopata estuvieron involucrados intelectuales indígenas con los que Churata mantuvo un diálogo mucho más fluido y enriquecedor que el compartido con los orkopatas mestizos. La crítica no ha reparado todavía en este detalle tan significativo, porque se ha dejado guiar por una lectura demasiado literal del archivo escrito dejado por los orkopatas. A primera vista, el Boletín Titikaka parecería haber privilegiado la intervención de intelectuales mestizos, pues son pocas las contribuciones firmadas por autores indígenas. Esa suposición empieza a relativizarse cuando obervamos que prácticamente la totalidad de libros, revistas y periódicos que se reseñaron carecen de autoría, sugiriendo la práctica de un trabajo colectivo que no necesitaba "firma de autor" para legitimarse. Una observación de Emilio Vásquez sobre el funcionamiento de los orkopata avala esta hipótesis: "[en Orkopata] se estudiaba de todo... frente al lago, los días domingos, se llevaban a cabo las confrontaciones de ideas y lecturas nuevas [...] Churata acotaba, corregía, aclaraba ideas, aportaba mayores conocimientos" (445).

$\mathrm{Si}$ a esto sumamos el conjunto de actividades extra-editoriales que promocionaban los orkopatas (festivales de teatro, música y danzas indígenas, escuelas indigenales con proyectos de alfabetización bilingüe, seminarios de cultura agraria, etc.) y el hecho tan singular de que el último número del Boletín, dedicado a la memoria de Mariátegui, cerrara con tres composiciones poéticas escritas en quechua y en aymara por Eustaquio Arewanka, Inocencio Mamani y el legendario maestro de Utawilaya Manuel Allqa Camacho (uno de los intelectuales aymaras más politizados, miembro del Comité Central Pro-Derecho Indígena Tahuantinsuyu y amigo personal de Churata), podemos calibrar la incidencia que la intelectualidad indígena puneña tuvo en el vanguardismo del Titikaka. No por casualidad, en su discurso al Congreso de la República, a Estrella Peralta no se le olvidó mencionar a los orkopatas indígenas, recalcando que en el caso de Allqa Camacho se trataba de "un amigo".

Revista Iberoamericana, Vol. LXXXI, Núm. 253, Octubre-Diciembre 2015, 989-1013 
Esta constelación de intelectualidad indígena, cuyas figuras señeras eran Guamán y Katari, le permitió a Churata proponer que en el Perú había sido desde la intervención indígena y desde la literatura andina que se articularon las primeras teorizaciones críticas del determinismo colonial y la hegemonía hispánica. Por eso le dolió tanto que Vallejo afirmara en "Contra el secreto profesional" que "nada en el vanguardismo que se producía en América era digno de originalidad porque todo ya había sido dicho y hecho en Europa", o que Mariátegui, en sus Siete ensayos, ni siquiera de pasada mencionara al vanguardismo puneño, que habría podido imprimir una diferencia significativa en su análisis del proceso de la literatura peruana. Llamar la atención sobre la existencia de vertientes plebeyas de pensamiento crítico como la de Guamán, Katari o el ensayado por el vanguardismo del Titikaka, abría la posiblidad de repensar el "proceso literario peruano" y problematizar la "nacionalidad" de un canon literario restringido a intereses y sensibilidades estéticas criollo-mestizas. Igualmente importante era enfatizar que tanto en Guamán como en Katari, esos plebeyismos se proponían desde un lenguaje que ya no era ni español ni vernacular, ni se acomodaba a las armonías del mestizaje. Era un engendro lingüístico que insinuaba hasta qué punto la literatura dejaba de ser un fenómeno "bellístrico" cuando lo que entraba en juego era acenturar una radical americana en el pensamiento de América (161). A Churata le indignaba que a mediados del siglo XX "todo lo que el indio veía con las elaboraciones de la imaginación le estaba negado", pero la agitación política y artística que generaban los ayllus de Puno y el Altiplano boliviano, le decía que "ese mutismo habrá de romperse un día, a juzgar de la magnitud de este mundo y de su proceso expansivo, [y que] se romperá por el lado aristárquico de las ruinas americanas: por el indio, que es lo único con régimen en sí mismo, con raíz y cosmos" (El pez de oro 184-185). De haber vivido las ultimidades del siglo XX y los inicios del XXI habría presenciado el resurgimiento masivo de las culturas y políticas indígenas en Bolivia, que provocaron la erosión del Estado Republicano y la emergencia de un Estado Plurinacional todavía en proceso de consolidación, pero suficiente para haber reorientado el curso de la cultura y la política. La tremenda actualidad que el pensamiento de Churata tiene hoy día entre los jóvenes escritores andinos deriva de la claridad con que vislumbró esa erosión y anticipó coyunturas inconcebibles para la época, como ésa de que la nacionalidad, es decir las mayorías, tomen el Estado. Veamos a Churata teorizando esa posibilidad:

Oigo a las minorías afirmar que ellas incorporarán a las mayorías a la nacionalidad... Argucia de tramposos: que tanto equivaldría a que la fontana, que se contiene en un cuenco de la mano, pretenda que ella incorporará la inmensidad de los océanos.

Si las minorías se apropian de los instrumentos del Estado, preveníos: sobrevendrá un cataclismo. No esperéis que os lleve de la mano el taimado politiquero: ¡id vosotros; tomad el Gobierno; disponed de él!... Si les dejáis despotricar os arrancarán los intestinos. Carecen de las materias de la vida; no tienen los sentidos genésicos de la

Revista Iberoamericana, Vol. LXXXI, Núm. 253, Octubre-Diciembre 2015, 989-1013 
acción; cualquier enano de los vuestros es un gigante a su lado, porque vosotros tenéis naturaleza y ellos materias rarificadas. Si hubiésemos de aceptar su predominio, sería -y es- sobre la base de que la nacionalidad por ese medio será proscrita del Estado; se ejercitará el gobierno con usurpación de autoridad, consagrando la negación de la Patria. (El pez de oro 915)

Igualmente sagaz y futurista, el proyecto de Borda asusta al lector desprevenido. El susto, en este caso, proviene de una descarga de furia. Borda fustiga la experiencia histórica de la modernidad y furiosamente se desentiende de esa tradición. En la escritura de $E l$ loco, se ficcionaliza en la figura de un personaje sin nombre (lo conocemos únicamente por el apelativo de Loco) que se piensa a sí mismo como "masa", como síntoma de una experiencia social de indignidad colectiva. Este loco, además de rechazar la historia "moderna" y "nacional" de Bolivia, pretende demolerla, y sobre sus ruinas proponer formas distintas de sociabilidad. Para ello, se autoconstruye como "demoledor" y desde esa beligerancia, sin huellas de indigenismo, paternalismo o discurso utópico, da forma a un vanguardismo descolonizador que ni él mismo pudo conceptualizar. Lo más cerca que estuvo de entender su propia obra fue cuando escribió, en el tomo tres de El loco, palabras verdaderamente conmovedoras: "en algo, no sé en qué, seré el primero y el único; pero la angustia me mata, porque no logro saber dónde está mi fuerza, no puedo calcular en la actividad de qué facultades está mi triunfo. Esto me enloquece" (III, 37).

Borda no se equivocó. Ese loco ficcionalizado fue evidentemente "el primero y el único" que en una Bolivia todavía conservadora y cargada de prejuicios racistas, planteó el ingreso a la literatura de lo marginal-popular-urbano y la posibilidad de una escritura descolonizada. Pero a diferencia de Churata, que siempre supo que su fuerza venía de las luchas indígenas por su autodeterminación política y cultural, Borda vivió atormentado por "no saber" dónde exactamente radicaba su fuerza. ¿Acaso en el proyecto descolonizador que movilizaba su obra? ¿Acaso en un proyecto estético que lo llevaba a concebir nuevos territorios en el horizonte de la creación artística? ¿Acaso en esa incontenible pulsión por demolerlo todo? ¿Acaso (y esto lo hace grande) en una conflictiva combinación de todo lo anterior? Cualquiera sea la respuesta, con Borda se expresó en los Andes lo que podría llamarse el último ismo vanguardista: el demolicionismo, que además de la demolición de una nación y de una cultura colonizada, proponía la demolición de la mansedumbre de los subalternos, a los que interpeló con inquietantes preguntas: ¿Cuándo reventará la dignidad humana? ¿Cuándo se sublevará la humillación?” (I, 79).

He iniciado estas páginas problematizando el rescate que el Estado peruano y el Boliviano están haciendo de la obra de Borda y Churata, y he discutido la dificultad de reintegrar acríticamente a una "literatura nacional" obras que fueron proscritas. Concluyo proponiendo que una manera de honrar los desafíos que estos escritores le plantearon

Revista Iberoamericana, Vol. LXXXI, Núm. 253, Octubre-Diciembre 2015, 989-1013 
al proceso literario peruano y boliviano sería enriqueciendo la reflexión crítica actual con sus planteamientos. Borda y Churata nos muestran que en la región andina toda vez que las mayorías (las masas, diría Borda) se enfrentan al Estado o intervienen la cultura, se producen transformaciones irreversibles - al margen del éxito o del fracaso que esas acciones puedan tener. El levantamiento de Tupac Katari, que concluyó con su descuartizamiento y con el de su compañera de vida, Bartolina Sisa, generó desarreglos que vulneraron en definitiva la estabilidad del orden colonial en Charcas. Así también El loco y El pez de oro provocaron transformaciones irreversibles en la literatura peruana y boliviana, acercándolas, finalmente, a la categoría de "literaturas nacionales". En Bolivia, el proceso se ha visto enriquecido, porque lo ha acompañado una voluntad política con capacidad de transformar un Estado Nacional creado por minorías criollo-mestizas, en un Estado Plurinacional cuyo compromiso con las mayorías está todavía por verse, pero que jurídicamente ya ha dado pasos fundamentales para una radical democratización de la cultura.

\section{BiBLIOGRAFíA}

Badini, Riccardo. "Simbología de El pez de oro". Simbología de El pez de oro. Riccardo Badini y otros. Lima: Editorial San Marcos, 2006. 7-14.

Boletín Titikaka. 1926-1928. Edición Facsimilar. 2 vols. Arequipa: Universidad Nacional de San Agustín, 2004.

Borda, Arturo. El loco. 3 vols. La Paz: Biblioteca Paceña. Honorable Alcaldía Municipal de La Paz, 1966.

Callo Cuno, Dante. “Aportes y equívocos de la crítica. A propósito del Boletín Titikaka". Identidades 58 (2004): 3-5.

"Boletín Titikaka, Segundo tramo". Boletín Titikaka. Edición Facsimilar. Arequipa-Perú: Universidad Nacional de San Agustín, 2004. 10 nos.

"Presentación”. Boletín Titikaka. Edición Facsimilar.Arequipa-Perú: Universidad Nacional de San Agustín, 2004. 24 nos.

"Vanguardismo andino en el Boletín Titikaka (1926-1930)". CELEHIS: Revista del Centro de Letras Hispanoamericanas 18 (2007): 219-245.

César, Ángeles L. "Entrevista a Marco Thomas Bosshard en torno a su libro Hacia una estética de la vanguardia andina. Gamaliel Churata entre el indigenismo y el surrealismo". 2002. <http://www.andes.missouri.edu/andes/cronicas/CAL_ bosshard.html>. 20 marzo 2015.

Churata, Gamaliel. “Cartas a Mariátegui”. José Carlos Mariátegui. Correspondencia (1915-1930). 2 tomos. Introducción, compilación y notas de Antonio Melis. Lima: Biblioteca Amauta, 1984. 193, 295, 384, 403, 432, 434, 550. 
“Conferencia”. 1966. Motivaciones del escritor. Arguedas, Alegría, Izquierdo Ríos, Churata. Lima: Universidad Nacional Federico Villarreal, 1989. 59-67. "Dialéctica del realismo psíquico. Segunda Conferencia en el cine Puno". 1965. Simbología de El pez de oro. Riccardo Badini y otros. Lima: Editorial San Marcos, 2006. 15-29. El pez de oro. Retablos del Laykhakuy. La Paz-Cochabamba: Editorial Canata, Talleres de la SIPC, 1957. [Reeditado en 1987 por José Luis Ayala (Lima: CORDEPUNO) y en 2012 por Helena Usandizaga (Madrid: Cátedra)]. La resurrección de la muertos. Alfabeto de lo incognoscible. Riccardo Badini, ed. Lima: Asamblea Nacional de Rectores, 2010. y otros. Trigo, estaño y mar. La Paz: Última Hora, 1950.

Cornejo Polar, Antonio. La formación de la tradición literaria en el Perú. Lima: CEP, 1989.

Díez de Medina, Fernando. "Gamaliel Churata y El pez de Oro" (El Diario. La Paz, Junio 1957). Fantasía coral. Rolando Díez de Medina, ed. La Paz: s.e., 2004.

Espezúa Salmón, Dorian. "Vanguardismo andino en el Boletín Titikaka". CELEHIS: Revista del Centro de Letras Hispanoamericanas 18 (2007): 219-45.

Finot, Enrique. Nueva historia de Bolivia. Ensayo de interpretación sociológica. 1946.

La Paz: Editorial Gisbert, 1954.

Flores Galindo, Alberto. Buscando un Inca. Identidad y utopía en los Andes. Lima: Instituto de Apoyo Agrario, 1987.

Guamán Poma de Ayala, Felipe. El primer Nueva corónica y buen gobierno. 1615. Segunda edición. John V. Murra y Rolena Adorno, eds. Trad. del Quechua, Jorge L. Urioste. México: Siglo XXI, 1988. 3 vols.

Heidegger, Martin. El ser y el tiempo. 1927. José Gaos, trad. México: Fondo de Cultura Económica, 1951.

Imaña Castro, Teodosio. "Katari y la acción pre-emancipadora". Presencia Literaria. 14 marzo 1971: 4.

López Lenzi, Yazmín. El laboratorio de la vanguardia literaria en el Perú. Lima: Horizonte, 1999.

Lora, Guillermo. “El anarquismo en Borda”. Páginas de mi archivo. La Paz: s.e., 1993. Mariátegui, José Carlos. Siete ensayos de interpretación de la realidad peruana. 1928. La Habana: Casa de las Américas, 1975.

Medinaceli, Carlos. "Epistolario" (1918-1944). Atrevámonos a ser bolivianos. Vida y epistolario de Carlos Medinaceli. Mariano Baptista Gumucio, ed. La Paz: Biblioteca Popular Boliviana de Última Hora, 1979.

Monasterios, Elizabeth. La vanguardia plebeya del Titikaka. Gamaliel Churata y otras beligerancias estéticas en los Andes. Lima/La Paz: IFEA/Plural, 2015. "La vanguardia plebeya del Titikaka". La Mariposa Mundial. Revista de literatura 19/20 (2012): 39-49.

Revista Iberoamericana, Vol. LXXXI, Núm. 253, Octubre-Diciembre 2015, 989-1013 
Montenegro, Carlos. Nacionalismo y coloniaje. 1943. La Paz: Editorial Juventud, 1993. Peralta, Estrella. "Palabras de agradecimiento de la hija de Gamaliel Churata". Los Andes /Nacional. 4 feb. 2012.<http://www.losandes.com.pe/Nacional/20120204/60545. html>. 20 marzo 2015.

Rodríguez Rea, Miguel Ángel. “Guía del Boletín Titikaka”. Hueso Húmero 11 (1981): 156-184.

Saenz, Jaime. “Arturo Borda”. Semanario Aquí. 12 nov. 1993. Vidas y muertes. La Paz: Huayna Potosí, 1979.

Sagrada Biblia. Versión de Eloíno Nácar Fuster, Alberto Colunga y Gaetano Cicognani. Madrid: Biblioteca de Autores Cristianos, 1957.

Schwartz, Jorge. Las vanguardias latinoamericanas. Textos programáticos y críticos. 1991. México: Fondo de Cultura Económica, 2006.

Thomson, Sinclair. Cuando sólo reinasen los indios. La política aymara en la era de la insurgencia. Trad. Silvia Rivera Cusicanqui. La Paz: Muela del Diablo Editores y Aruwiyiri, Editorial del THOA, 2006.

Unruh, Vicky. Latin American Vanguards. The Art of Contentious Encounters. Berkeley: U of California P, 1994.

Vallejo, César. "Contra el secreto profesional” (Variedades. Lima: 5 julio 1927). Artículos y crónicas completos. Vol. I. Lima: Pontificia Universidad Católica del Perú, 2002. 421-25.

Vásquez, Emilio. “Churata y su obra”. Antología y valoración. Lima: Ediciones Instituto Puneño de Cultura, 1971.

Vich, Cynthia. Indigenismo de vanguardia en el Perú. Un estudio sobre el Boletín Titikaka. Lima: Pontificia Universidad Católica del Perú, 2000.

Wiethüchter, Blanca y Alba María Paz-Soldán, eds. Hacia una historia crítica de la literatura en Bolivia. La Paz: PIEB, 2002. 2 Vols.

Wise, David. "Vanguardismo a 3800 metros: el caso del Boletín Titikaka (Puno 19261930)". Revista de Crítica Literaria Latinoamericana 10/20 (1984): 89-100.

Yerba Mala Cartonera. "Yerba Mala Cartonera". Akademia Cartonera: Un ABC de las editoriales cartoneras en América Latina. Ksenija Bilbija y Paloma Celis Carbajal, eds. Wisconsin: University of Wisconsin-Madison Libraries, 2009. 125-32.

Zevallos Aguilar, Ulises Juan. "Vanguardismo literario andino y modernidades alternativas en el Sur peruano (1900-1930)”. Boletín Hispánico Helvético 4 (2004): 79-91

Indigenismo y nación. Retos a la representacióon de la subalternidad aymara y quechua en el Boletín Titikaka (1926-1930). Lima: Instituto Francés de Estudios Andinos/Banco Central de Reserva del Perú, 2002.

Revista Iberoamericana, Vol. LXXXI, Núm. 253, Octubre-Diciembre 2015, 989-1013 
